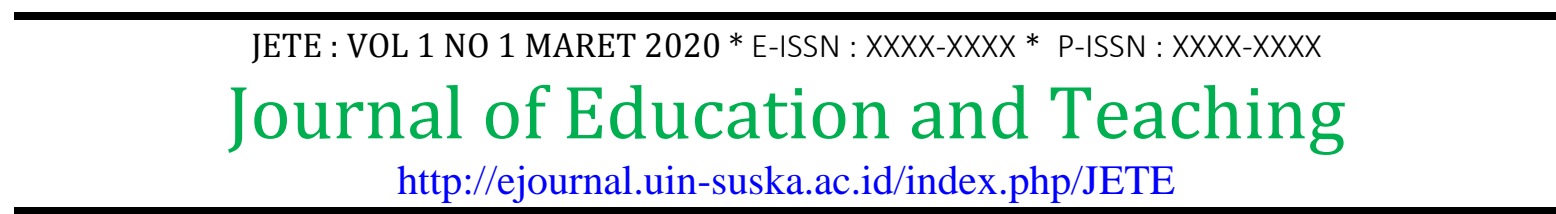

\title{
UPAYA MENINGKATKAN HASIL BELAJAR PESERTA DIDIK PADA PEMBELAJARAN IPA POKOK BAHASAN KLASIFIKASI MAKHLUK HIDUP DENGAN MENGGUNAKAN MODELPROBLEM BASED LEARNING DI KELAS VII A SMP NEGERI 4 TAPUNG HILIR
}

\author{
Nuryati \\ SMP Negeri 4 Tapung Hilir Kampar, Indonesia ${ }^{1}$ \\ Email: nuryati894@yahoo.com*1
}

\begin{abstract}
ABSTRAK
Desain penelitian ini menggunakan penelitian tindakan kelas. Penelitian Tindakan Kelas (Classroom Action Research). Ada empat tahapan dalam penelitian tindakan, yaitu (1) perencanaan, (2) pelaksanaan, (3) pengamatan, dan (4) refleksi. Dalam penelitian ini, peneliti melakukan kegiatan dalam dua siklus dengan masing-masing siklus terdiri dari satu kali pertemuan. Hasil penelitian ini memaparkan data hasil belajar peserta didik pada pokok bahasan Klasifikasi Makhluk Hidup dengan menggunakan model Problem Based Learning pada peserta didik Kelas VII A SMP Negeri 4 Tapung Hilir. Data yang dikumpulkan peneliti dari hasil belajar peserta didik melalui tes tertulis. Dari hasil penilaian yang dilakukan pada siklus I yakni diperoleh nilai 50-56 dengan frekuensi 2 (10\%), nilai 57-63 dengan frekuensi 4 (20\%), nilai 64-70 dengan frekuensi 4 (20\%), nilai 71-77 dengan frekuensi 5 (25\%), nilai 78-85 dengan frekuensi 5 (25\%). Dari hasil penilaian yang dilakukan pada siklus II yakni diperoleh nilai 65-71 dengan frekuensi 2 (10\%), nilai 72-78 dengan frekuensi 3 (15\%), nilai 79-85 dengan frekuensi 6 (30\%), nilai 86-92 dengan frekuensi 3 (15\%), nilai 93-100 dengan frekuensi $6(30 \%)$. Berdasarkan data yang diperoleh pada Siklus I menunjukan bahwa jumlah peserta didik yang tuntas sebanyak 10 peserta didik atau (50\%), tidak tuntas sebanyak 10 peserta didik atau (50\%), sedangkan siklus II peserta didik yang tuntas sebanyak 17 peserta didik atau (85\%), dan tidak tuntas 3 peserta didik atau (15\%).
\end{abstract}

Kata Kunci: Tindakan ; Belajar; Peserta didik; Makhluk; Model

\section{EFFORTS TO IMPROVE STUDENTS 'LEARNING OUTCOMES IN LEARNING SCIENCE LEARNING CLASSIFICATION OF LIFE BEHAVIOR USING MODELPROBLEM BASED LEARNING IN CLASS VII A SMP NEGERI 4 TAPUNG HILIR}

\section{ABSTRACT}

The design of this study uses classroom action research. Classroom Action Research. There are four stages in action research, namely (1) planning, (2) implementation, (3) 
observation, and (4) reflection. In this study, researchers conducted activities in two cycles with each cycle consisting of one meeting. The results of this study describe students' learning outcomes data on the subject Classification of Living Things by using the Problem Based Learning model on Class VII A students of SMP Negeri 4 Tapung Hilir. Data collected by researchers from the learning outcomes of students through written tests. From the results of the assessment conducted in the first cycle that is obtained a value of 50-56 with a frequency of 2 (10\%), a value of 57-63 with a frequency of 4 (20\%), a value of 64-70 with a frequency of 4 (20\%), a value of $71-77$ with a frequency of 5 (25\%), a value of 78-85 with a frequency of 5 (25\%). From the results of the assessment conducted in the second cycle that is obtained a value of 65-71 with a frequency of 2 (10\%), a value of 72-78 with a frequency of $3(15 \%)$, a value of 79-85 with a frequency of $6(30 \%)$, a value of 86-92 with a frequency of 3 (15\%), a value of 93-100 with a frequency of 6 (30\%). Based on the data obtained in Cycle I shows that the number of students who completed as many as 10 students or (50\%), not complete as many as 10 students or (50\%), while the second cycle of students who completed as many as 17 students or (85\%), and incomplete 3 students or (15\%).

Keywords: Action; Study; Learners; Creature; Model

\section{PENDAHULUAN}

Guru dalam tugasnya sebagai pendidik.,dalam hal ini guru ikut bertanggung jawab atas rendahnya kwalitas peserta didik yang dihasilkannya, khususnya mata pelajaran IPA peserta didik kelas VIIA SMP N 4 Tapung Hilir. Guru sebagai salah satu komponen penting dalam sekolah harus memiliki kemampuan profesional yang memadai agar mampu mencapai tujuan pendidikan Nasional. Guru tidak akan berarti apa-apa tanpa kehadiran peserta didik karena objek utama pengembangan adalah peserta didik, terutama sekali kemampuan profesional, keluasan dan kedalaman wawasan yang digunakan sebagai landasan dalam mengambil keputusan. Guru harus kaya dengan inovasi kreatif dalam memilih strategi atau model pembelajaran yang digunakan.

Berdasarkan komponen-komponen yang dijabarkan di atas, maka salah satu yang menjadi persoalan dalam penelitian tindakan kelas ini bahwa dalam pembelajaran IPA menunjukkan tingkat penguasaan peserta didik yang sangat rendah. Hal tersebut terbukti dari nilai peserta didik setelah beberapa kali diadakan ulangan (evaluasi). Hasil ulangan pada mata pelajaran IPA masih sangat rendah yaitu mendapat rata-rata kelas 60 dan belum mengalami ketuntasan, sedangkan nilai ketuntasan minimum SMP N 4 Tapung Hilir yaitu 75 .

Masalah pembelajaran tersebut kemungkinan besar dikarenakan pendekatan atau metode yang digunakan oleh guru tidak sesui dengan karakter dari materi mata pelajaran yang disampaikan, dalam hal ini sains atau IPA. Oleh karena itu perlu adanya inovasi dan pendekatan atau metode pembelajaran yang dapat menggairahkan atau menyegarkan dalam pembelajaran IPA.

Berdasar pada kenyataan di atas maka peneliti mengambil inisiatif pemecahan masalah yaitu dengan menggunakan model Problem Based Learning, hal ini sesuai dengan kurikulum 2013 di satuan pendidikan menekankan dalam pembelajarannya menggunakan pendekatan saintifik yang salah satu didalamnya terdapat model Problem Based Learning. 
Adapun alasan mengapa peneliti menggunakan metode Problem Based Learning karena dalam model ini dapat (1) Mendorong peserta didik untuk melakukan kerja sama dalam menyelesaikan tugas, (2) Mendorong peserta didik melakukan pengamatan dan dialog dengan orang lain, (3) Melibatkan peserta didik dalam penyelidikan pilihan sendiri, (4) Membantu peserta didik menjadi pembelajar yang mandiri.

Berdasarkan latar belakang masalah di atas, maka rumusan masalah yang akan dibahas dalam penelitian ini adalah: Apakah melalui penggunaan model Problem Based Learning dapat meningkatkan hasil belajar peserta didik pada pembelajaran IPA pokok bahasan Klasifikasi makhluk hidup di kelas VIIA SMP N 4 Tapung Hilir?

Dari rumusan masalah di atas maka, penelitian ini bertujuan untuk meningkatkan hasil belajar peserta didik pada pembelajaran IPA pokok bahasan Klasifikasi makhluk hidup di kelas VIIA SMP N 4 Tapung Hilir melalui penggunaan model Problem Based Learning.

\section{METODE PENELITIAN}

Desain penelitian ini menggunakan penelitian tindakan kelas. Penelitian Tindakan Kelas (Classroom Action Research). Arikunto (2010:16) menjelaskan ada empat tahapan dalam penelitian tindakan, yaitu (1) perencanaan, (2) pelaksanaan, (3) pengamatan, dan (4) refleksi.

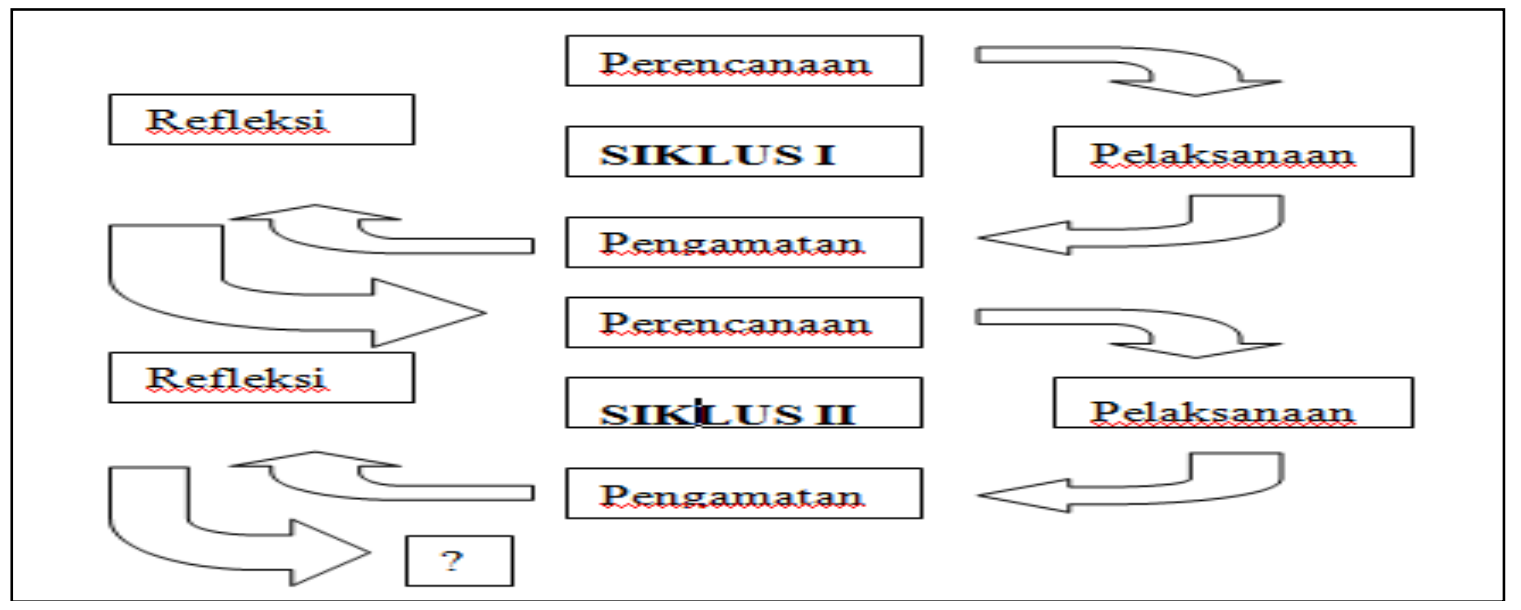

Gambar 1. Alur Kegiatan Pemecahan Masalah (Arikunto, 2010:16)

Subjek penelitian ini adalah peserta didik kelas VIIA SMP N 4 Tapung Hilir, Jumlah peserta didik sebanyak 20 peserta didik terdiri dari laki-laki berjumlah 10 orang dan perempuan berjumlah 10 orang.

Untuk mengukur ketuntasan siswa, maka peneliti memakai pedoman penilaian dari pusat penilaian (Depdiknas,2007:367), yaitu sebagai berikut:

Nilai Tes : $\quad \frac{\text { Jumlah Skor Yang Diproleh }}{\text { Jumlah }} \times 100$

Ketuntasan individu tercapai apabila siswa mencapai nilai 75 dari hasil tes. Ketuntasan klasikal tercapai apabila $75 \%$ dari seluruh siswa . 


\section{HASIL DAN PEMBAHASAN}

Hasil penelitian ini memaparkan data hasil belajar peserta didik pada pokok bahasan Klasifikasi Makhluk Hidup dengan menggunakan model Problem Based Learning pada peserta didik Kelas VII A SMP Negeri 4 Tapung Hilir. Data yang dikumpulkan peneliti dari hasil belajar peserta didik melalui tes tertulis

\section{Data Siklus I}

\section{a. Pelaksanaan}

Untuk memperoleh data pada siklus I dilakukan dalam satu kali pertemuan, langkah-langkah pembelajaran yang dimulai dari guru menyiapkan siswa secara psikis dan fisik untuk mengikuti proses pembelajaran dengan memberi salam, berdoa dan menecek kehadiran siswa, menyampaikan tujuan pembelajaran dan menjelaskan tentang model pembelajaran yang akan digunakan selama proses pembelajaran hingga memberikan suatu permasalahan kepada peserta didik dengan menggunakan LKS, mengorganisasikan peserta didik dengan membentuk kelompok heterogen untuk memecahkan permasalahan yang ada pada LKS dengan mengumpulkan informasi dan mengelolah informasi dengan cara melakukan tanya jawab dalam kelompok, menganalisis, menalar, meneliti, sampai dengan menyimpulkan serta menyajikan dengan mempresentasikan hasil diskusi,terakhir peserta didik melakukan evaluasi . Dari hasil penilaian evaluasi tersebut diperoleh data hasil penilaian tiap-tiap peserta didik pada siklus I, untuk lebih jelas dapat dilihat pada penjelasan dibawah ini.

Dari hasil penilaian yang dilakukan pada siklus I yakni diperoleh nilai 50-56 dengan frekuensi 2 (10\%), nilai 57-63 dengan frekuensi 4 (20\%), nilai 64-70 dengan frekuensi 4 (20\%), nilai 71-77 dengan frekuensi 5 (25\%), nilai 78-85 dengan frekuensi 5 (25\%). Di bawah ini merupakan tabel dan grafik distribusi data nilai berdasarkan hasil kemampuan peserta didik yaitu sebagai berikut:

Tabel 4. Distribusi Frekuensi Data Nilai Siklus I

\begin{tabular}{rrcc}
\hline No & INTERVAL & FREKUENSI & PERSENTASE \\
\hline 1 & $50-56$ & 2 & $10 \%$ \\
2 & $57-63$ & 4 & $20 \%$ \\
3 & $64-70$ & 4 & $20 \%$ \\
4 & $71-77$ & 5 & $25 \%$ \\
5 & $78-85$ & 5 & $25 \%$ \\
& JUMLAH & $\mathbf{2 0}$ & $\mathbf{1 0 0 \%}$ \\
\hline
\end{tabular}




\section{Grafik 2. Hasil Tes Siklus I}

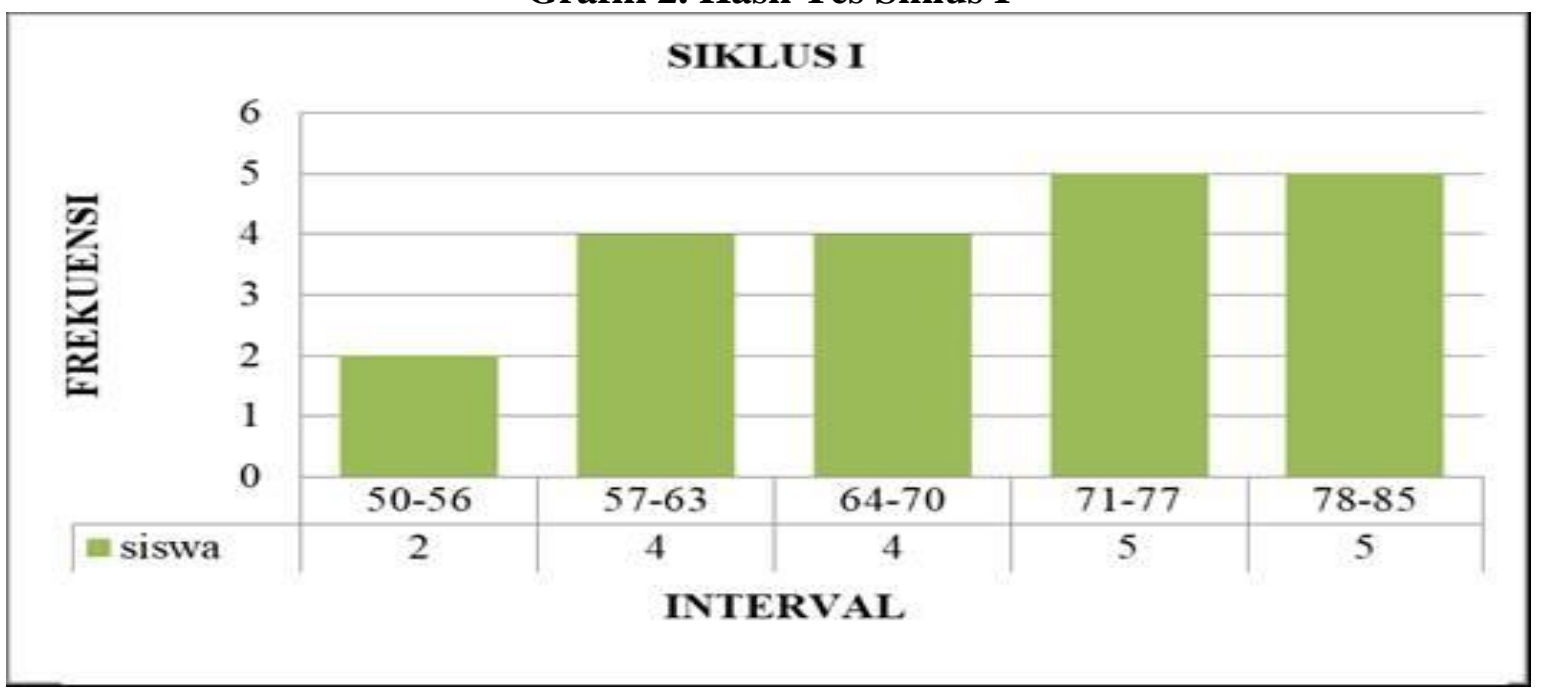

\section{b. Observasi}

Adapun lembar observasi yang diterapkan pada penelitian ini berupa kegiatan peserta didik di dalam kelas selama proses pembelajaran berlangsung.

\section{Lembar Observasi Peserta Didik}

\begin{tabular}{clc} 
No & \multicolumn{1}{c}{ Komponen Yang Diamati } & Jlh Peserta Didik \\
\hline 1. & $\begin{array}{l}\text { Peserta didik yang hadir pada saat pembelajaran } \\
\text { 2. }\end{array}$ & $\begin{array}{l}\text { Peserta didik yang melakukan kegitan lain pada saat pembahasan } \\
\text { materi pembelajaran dalam diskusi }\end{array}$ \\
3. & $\begin{array}{l}\text { Peserta didik yang berani mengajukan pertanyaan } \\
\text { Peserta didik yang berani menjawab pertanyaan dari peserta didik }\end{array}$ & 10 \\
4. & $\begin{array}{l}\text { lain (memberikan penjelasan) } \\
\text { Peserta didik yang menghargai pendapat, ide dan saran dari }\end{array}$ & 4 \\
6. & $\begin{array}{l}\text { kelompok lain. } \\
\text { Peserta didik yang mampu bekerja sama pada saat kerja kelompok }\end{array}$ & 10 \\
\hline
\end{tabular}

Berdasarkan tabel di atas dapat dinyatakan bahwa :

a. Kehadiran peserta didik 20 orang atau $100 \%$.

b. Peserta didik yang melakukan kegiatan lain pada saat pembahasan materi ada 10 orang atau $50 \%$

c. Peserta didik yang berani mengajukan pertanyaan ada 6 orang atau $30 \%$.

d. Peserta didik yang berani menjawab pertanyaan dari peserta didik lain (memberikan penjelasan) ada 4 orang atau $20 \%$.

e. Peserta didik yang menghargai pendapat, ide dan saran dari kelompok lain ada 10 orang atau $50 \%$. 
f. Peserta didik yang mampu bekerja sama pada saat kerja kelompok ada 10 orang atau 50 $\%$.

\section{c. Refleksi}

Pada tahap refleksi ini hasil yang diperoleh pada tahap observasi dikumpulkan untuk di analisis. Peneliti melakukan refleksi dengan melihat data observasi dan hasil tes akhir kegiatan yang telah dilakukan kepada kemampuan siswa. Hal-hal yang belum tercapai sebagian siswa belum mampu mengemukakan dan mengajukan pendapatnya, masih banyak siswa yang tidak aktif dalam menyelesaikan tugas yang diberikan, siswa yang malu mengerjakan hasil pekerjaannya di depan kelas .dan untuk ketuntasan klasikal hasil belajar peserta didik hanya mencapai $50 \%$ belum mencapai target dari yang diharapkan yaitu $75 \%$. Hasil analisisa yang dilaksanakan dalam tahap ini akan dipergunakan sebagai perbaikan dalam melaksanakan siklus II.

\section{Data Siklus II}

\section{a. Pelaksanaan}

Hasil data pelaksanaan perbaikan pembelajaran yang dilaksanakan dengan menempuh langkah-langkah pembelajaran yang dimulai dari persiapan sarana pendukung, dilakukan perencanaan siklus dan melakukan penilaian tes di akhir siklus. Dari hasil penilaian tersebut diperoleh data hasil penilaian dengan perolehan nilai tiap-tiap peserta didik pada siklus II, untuk lebih jelas dapat dilihat dari penjelasan di bawah ini.

Dari hasil penilaian yang dilakukan pada siklus II yakni diperoleh nilai 65-71 dengan frekuensi 2 (10\%), nilai 72-78 dengan frekuensi 3 (15\%), nilai 79-85 dengan frekuensi 6 (30\%), nilai 86-92 dengan frekuensi 3 (15\%), nilai 93-100 dengan frekuensi 6 (30\%). Di bawah ini merupakan tabel dan grafik distribusi data nilai berdasarkan hasil kemampuan peserta didik yaitu sebagai berikut:

Tabel 5. Distribusi Frekuensi Data Hasil Siklus II

\begin{tabular}{cccc}
\hline NO & INTERVAL & FREKUENSI & PERSENTASE \\
\hline 1 & $65-71$ & 2 & $10 \%$ \\
2 & $72-78$ & 3 & $15 \%$ \\
3 & $79-85$ & 6 & $30 \%$ \\
4 & $86-92$ & 3 & $15 \%$ \\
5 & $93-100$ & 6 & $30 \%$ \\
& JUMLAH & $\mathbf{2 0}$ & $\mathbf{1 0 0 \%}$ \\
\hline
\end{tabular}




\section{Grafik 2 : Hasil Tes Siklus II}

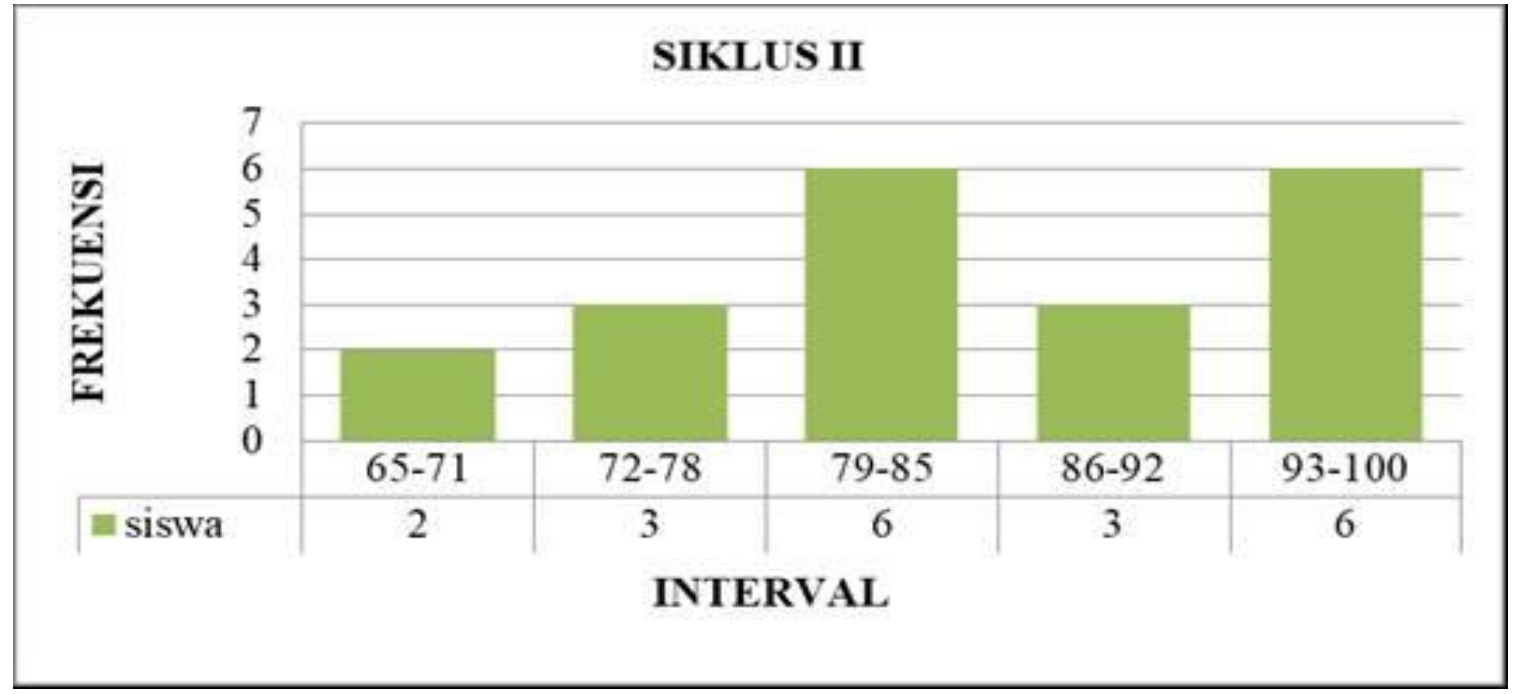

\section{b. Observasi}

Adapun lembar observasi yang diterapkan pada penelitian ini berupa kegiatan peserta didik di dalam kelas selama proses pembelajaran berlangsung

\section{Lembar Observasi Peserta Didik}

\begin{tabular}{llc}
\hline No & \multicolumn{1}{c}{ Komponen Yang Diamati } & $\begin{array}{c}\text { Jlh Peserta } \\
\text { Didik }\end{array}$ \\
\hline 1. & $\begin{array}{l}\text { Peserta didik yang hadir pada saat pembelajaran } \\
\text { 2. }\end{array}$ & 20 \\
peserta didik yang melakukan kegitan lain pada saat pembahasan materi & 2 \\
3. & $\begin{array}{l}\text { Peserta didik yang berani mengajukan pertanyaan } \\
\text { Peserta didik yang berani menjawab pertanyaan dari peserta didik lain }\end{array}$ & 12 \\
4. & $\begin{array}{l}\text { (memberikan penjelasan) } \\
\text { 5. }\end{array}$ & 10 \\
6. & Peserta didik yang menghargai pendapat, ide dan saran dari kelompok & 20 \\
\hline
\end{tabular}

Berdasarkan tabel di atas dapat dinyatakan bahwa :

a. Kehadiran peserta didik 20 orang atau $100 \%$.

b. Peserta didik yang melakukan kegiatan lain pada saat pembahasan materi ada 2 orang atau $10 \%$

c. Peserta didik yang berani mengajukan pertanyaan ada 12 orang atau $60 \%$.

d. Peserta didik yang berani menjawab pertanyaan dari peserta didik lain (memberikan penjelasan) ada 10 orang atau 50\%.

e. Peserta didik yang menghargai pendapat, ide dan saran dari kelompok lain ada 
20 orang atau $100 \%$.

f. Peserta didik yang mampu bekerja sama pada saat kerja kelompok ada 20 orang atau $100 \%$.

\section{c. Refleksi}

Pelaksanaan pada siklus II, hasil yang diperoleh pada tahap observasi dan hasil tes terakhir secara garis besar berlangsung dengan baik dan sesuai rencana pembelajaran. Karena ketuntasan belajar siswa sudah tercapai. Dengan menggunakan medel Problem Based Learning pada pelajaran IPA, diperoleh bahwa hasil belajar IPA meningkat. Hal ini tampak dari hasil tes yang dilakukan setelah akhir pelaksanaan siklus, Ketuntasan belajar klasikal siswa $80 \%$.

\section{Pengujian Pertanyaan Penelitian}

Berdasarkan data yang diperoleh pada Siklus I menunjukan bahwa jumlah peserta didik yang tuntas sebanyak 10 peserta didik atau (50\%), tidak tuntas sebanyak 10 peserta didik atau (50\%), sedangkan siklus II peserta didik yang tuntas sebanyak 17 peserta didik atau (85\%), dan tidak tuntas 3 peserta didik atau (15\%). Untuk lebih jelas mengenai peningkatan hasil belajar peserta didik, dapat dilihat keterangan pembelajaran peserta didik dalam menggunakan model Problem Based Learning dari data siklus I, dan siklus II pada tabel 6 .

Tabel 6. Perbandingan Hasil Belajar Model Problem Based Learning

\begin{tabular}{cccc}
\hline Kategoori & Siklus I & Siklus II & Ket \\
\hline Tuntas & $10(50 \%)$ & $17(85 \%)$ & Adanya peningkatan \\
Tidak Tuntas & $10(50 \%)$ & $3(15 \%)$ & \\
Jumlah & $24(100 \%)$ & $24(100 \%)$ & \\
\hline
\end{tabular}

Dari tabel di atas, dapat disimpulkan pada siklus I peserta didik yang tuntas sebanyak 10 orang, dan yang tidak tuntas sebanyak 10 orang, dan siklus II peserta didik yang tuntas sebanyak 17 orang, dan tidak tuntas 3 orang, dengan pembelajaran model Problem Based Learning terdapat peningkatan hasil belajar siswa.

\section{Pembahasan}

Berdasarkan dari data hasil penelitian, untuk mengetahui peningkatan hasil belajar dengan menggunakan model Problem Based Learning pada peserta didik Kelas VII A SMP Negeri 4 Tapung Hilir dapat dilihat dari hasil penilaian yang dilakukan pada siklus I yakni diperoleh nilai maksimum adalah 85 dan nilai minimum adalah 50, sedangkan peserta didik yang tuntas sebanyak 10 peserta didik atau (50\%), dan tidak tuntas sebanyak 10 peserta didik atau (50\%), sedangkan yang pada siklus II yakni diperoleh nilai maksimum adalah 100 sedangkan nilai minimum yang diperoleh adalah 65, serta peserta didik yang tuntas sebanyak 17 peserta didik atau (85\%), dan tidak tuntas sebanyak 3 peserta didik atau (15\%). Dari hasil pembelajaran siklus II masih ada indikator yang rendah yaitu peserta didik belum sepenuhnya dapat menguasai materi klasifikasi makluk hidup, Ada beberapa siswa yang melakukan kesalahan dalam 
menjawab soal- soal yang diberikan, namun dilihat dari data siklus I dan siklus II, membuktikan adanya peningkatan hasil belajar peserta didik kelas VII A di SMP Negeri 4 Tapung Hilir dari kondisi awal peserta didik yang tuntas sebanyak 10 peserta didik menjadi 17 peserta didik dan peserta didik yang belum tuntas sebanyak 10 peserta didik menjadi 3.

Peningkatan hasil belajar peserta Didik kelas VII A di SMP Negeri 4 Tapung Hilir ini dikarenakan adanya ketertarikan peserta didik dalam menggunakan model Problem Based Learning. Para peserta didik termotivasi untuk belajar, baik karena motivasi nilai, interaksi belajar bersama teman-teman sehingga dapat meningkatkan prestasi belajar peserta didik.

\section{KESIMPULAN}

Berdasarkan hasil penelitian tindakan kelas yang telah dilakukan pada siswa kelas VII A SMPN 4 Tapung Hilir, maka dapat disimpulkan sebagai berikut:

Penggunaan model Problem Based Learning pada pembelajaran IPA dapat meningkatkan hasil belajar siswa. Hasil belajar tersebut didapatkan dari penggabungan tiga aspek yaitu kognitif, afektif dan psikomotor. Rata-rata hasil belajar pada siklus I adalah sebesar 70,5 dengan persentase ketuntasan sebesar 50\% . Kemudian, pada siklus II Rata-rata hasil belajar siswa adalah sebesar 84,25 dengan persentase ketuntasan sebesar $80 \%$. Terjadi peningkatan hasil belajar siswa dari siklus I ke siklus II sebesar 13,75 dan peningkatan persentase ketuntasan sebesar $30 \%$.

\section{DAFTAR PUSTAKA}

Arikunto, S. (2010). Penelitian Tindakan Kelas. Jakarta: Bumi Aksara

Depdiknas. (2007). Sistem Pendidikan Nasional. Jakarta: Departemen Pendidikan Nasional

Oemar Hamalik. Proses Belajar Mengajar. Jakarta: Bumi Aksara.

Mulyasa. 2008. Menjadi Guru Profesional Menciptakan Pembelajaran Aktif dan Kreatif. Bandung: PT Remaja Rosdakarya.

Anas Sudijono. 2007. Pengantar Evaluasi Pendidikan. Jakarta: PT Raja Grafindo Persada

Sumiati dan Asra. 2007. Metode Pembelajaran. Bandung: CV Wacana Media. 